\title{
Habitat use and resource tracking by African Ceratogymna hornbills: implications for seed dispersal and forest conservation
}

\author{
Kenneth D. Whitney ${ }^{1}$ and Thomas B. Smith \\ Department of Biology, San Francisco State University, 1600 Holloway Avenue, San Francisco, California 94132, USA and \\ Center for Population Biology, University of California, Davis, California 95616-8755, USA
}

(Received 3 September 1997; accepted 6 January 1997)

\begin{abstract}
Conservation of tropical forests requires an understanding of the seasonal patterns of abundance and distribution of important seed dispersers. In the forests of Central Africa, three species of hornbills in the genus Ceratogymna (Aves: Bucerotidae) provide dispersal for over 50 species of trees and lianas, yet their ecology is poorly known. We present the first empirical evidence for resource tracking and large-scale movements by two of these species, which were previously considered resident. Hornbill numbers and fruit production were estimated over a one-year period in the Dja Reserve, Cameroon. Monthly abundances of C. atrata and C. cylindricus varied four- and 12-fold, respectively, and were predicted by community fruit availability as measured by fruitfall on a $4.3 \mathrm{~km}$ trail. In contrast, $C$. fistulator abundances varied little and were not related to fruit availability. Synchronous population fluctuations in sites $22 \mathrm{~km}$ distant were observed for atrata and cylindricus, but not for fistulator. Together, these results indicate that atrata and cylindricus populations track fruit resources via seasonal emigrations, while the fistulator population appears to be relatively sedentary. Comparisons of hornbill densities in primary and secondary forests suggest that they are important dispersers in both habitats, and will likely play larger roles in central African forest regeneration as more vulnerable seed dispersers are removed by hunting. If large seasonal movements of hornbills turn out to be a general phenomenon, effective management of central African forest reserves will require greater emphasis on reserve connectivity and on seasonal and spatial patterns of fruit production.
\end{abstract}

\section{INTRODUCTION}

Changes in animal abundance in space and time are critically important when the species under consideration are integral to community processes. Seed dispersers provide a case in point. Because of their roles in the reproductive life histories of many plants (Howe, 1984, 1990; Stiles, 1992; Willson, 1992; Herrera, 1995), population fluctuations of seed dispersers can have substantial effects on communities. In the extreme case of extinction of the seed dispersing species, plant recruitment can be severely curtailed (Temple, 1977; Bond \& Slingsby, 1984; Witmer \& Cheke, 1991); conversely, large increases in seed disperser populations accompanying invasions of new habitats can have dramatic effects on plant community composition (e.g. Whittaker \& Jones, 1994) and ecosystem function (e.g. Vitousek

${ }^{1}$ All correspondence to: Kenneth D. Whitney Present address: Center for Population Biology, University of California, Davis, California 95616-8755, USA.
\& Walker, 1989). Even less dramatic fluctuations, such as local increases in bird abundance that follow the construction of artificial perches, can change patterns of seed rain and alter the species diversity of the seedling bank (McDonnell \& Stiles, 1983; McClanahan \& Wolfe, 1993). In tropical forests, where 62-93\% of the woody flora is adapted for vertebrate dispersal (Jordano, 1992), fluctuations in disperser abundances are likely to prove particularly important.

Disperser populations in tropical forests are affected by habitat disturbance and fragmentation. The combined effects of logging and land clearance for agriculture have resulted in vast changes in the availability of food, suitable breeding areas, and other resources that are important to animals. However, long-term studies that monitor disperser populations concurrently with changes in habitat structure and quality are scarce (but see Bierregaard \& Lovejoy, 1988; Johns, 1989). In the absence of longterm data for many regions, comparing animal densities in adjacent undisturbed and disturbed forest sites (e.g. Johns \& Skorupa, 1987) is an efficient method for 
evaluating the effects of disturbance on particular dispersers.

Disperser populations in tropical forests are also highly affected by the availability of fruit. Fruit exhibits a high degree of spatial and temporal patchiness in most tropical forests (Fleming, Breitwisch \& Whitesides, 1987; Fleming, 1992; Jordano, 1992; van Schaik, Terborgh \& Wright, 1993). Periods of fruit scarcity and abundance have been related to seasonal cycles of rainfall (Foster, 1982; Fleming et al., 1987), temperature (Tutin \& Fernandez, 1993), and insolation (White, 1994a), and are likely controlled by the interaction of these and a variety of other factors (van Schaik et al., 1993). Spatially, large differences in fruit availability have been recorded over distances as small as $2 \mathrm{~km}$ (van Schaik, 1986). Frugivores can respond to this spatiotemporal patchiness through resource tracking, with consequences for their demography, physiology, foraging movements, social organization, and mating systems (Fleming, 1992). Resource tracking via daily and/or seasonal foraging movements has been demonstrated for many frugivore taxa; recent discussions include Fleming (1992), Jordano (1992), and van Schaik et al. (1993). Fleming et al. (1987) speculate that, because of a higher degree of spatiotemporal patchiness of fruit in the Old World, nomadic movements of frugivores may be more common in the Old World than in the New World. Their evaluation is based upon data from the Asian tropics and the Neotropics; further evidence is needed from the Afrotropics before this hypothesis can be evaluated, as data on frugivore movements in the Afrotropics are scarce (Thomas, 1983; White, 1994b).

Large hornbills in the genus Ceratogymna (Aves: Bucerotidae) are common members of the frugivore community throughout lowland tropical rain forest in Africa (Kemp, 1995), but their ecology has only recently been addressed quantitatively (Kalina, 1988; Whitney et al., 1998). In the Dja Reserve in southern Cameroon, the black-casqued hornbill, $C$. atrata, the white-thighed hornbill, C. cylindricus albotibialis, and the piping hornbill, C. fistulator sharpii are large, $0.5-1.3 \mathrm{~kg}$ birds that consume the fruits and disperse the seeds of at least 56 species of trees and lianas belonging to at least 20 plant families (Whitney et al., 1998). The majority of seeds swallowed are moved away from parent plants, seeds are rarely harmed during gut passage, and most species germinate at rates equal to or greater than controls, suggesting that Ceratogymna hornbills are important seed dispersers (Whitney et al., 1998). Ceratogymna subcylindricus has been reported from the Dja Reserve (Christy, 1994) but is rare (R. Fotso, pers. comm.), and was not observed during this study. The remaining four species of hornbills in the Dja Reserve assemblage - Tockus hartlaubi, T. camurus, T. albocristatus, and T. fasciatus - are smaller and less frugivorous than the Ceratogymna species ( $K$. Whitney, unpubl. data; Kemp, 1995).

In this paper, we use line transect methods to estimate the densities and biomasses of six of the seven species in the hornbill assemblage of the Dja Reserve, southern Cameroon. We contrast hornbill densities in mature and secondary forest sites in order to make some general predictions about the effects of habitat disturbance on hornbill populations, and about the types of habitats in which hornbills are likely to play an important role in seed dispersal. In addition, we examine within-site habitat use for the two largest and most common species, atrata and cylindricus. We use a measure of community fruit availability (the raked-trail survey) to examine whether Ceratogymna hornbill population fluctuations track seasonal changes in fruit availability. Finally, we evaluate evidence for intratropical migration using data on between-site synchrony in Ceratogymna hornbill abundances.

\section{METHODS}

\section{Study sites}

The study took place from January to December 1994 at two sites in southern Cameroon, one inside and one bordering the Dja Reserve. At 526000 hectares, the Dja Reserve (Fig. 1) is the largest protected area in Cameroon and is an IUCN Biosphere Reserve (IUCN, 1987). The vegetation is semi-deciduous tropical rain forest (Letouzey, 1968), and has strong affiliations with other regions of the Congo Basin forest to the south and weaker affiliations with the evergreen Atlantic coastal forest to the west. Elevations in the Reserve range from $400-800 \mathrm{~m}$. The climate is characterized by two wet and two dry seasons, with major and minor rainfall peaks in September and May, respectively. Average annual rainfall is approximately $1600 \mathrm{~mm}$ (Laclavère, 1980) and was $1669 \mathrm{~mm}$ during 1994.

\section{Mature forest site: Bouamir Research Station}

The mature forest site is a $25 \mathrm{~km}^{2}$ square centered on the Bouamir Research Station ( $\left.3^{\circ} 11^{\prime} 27^{\prime \prime N}, 12^{\circ} 48^{\prime} 41 " \mathrm{E}\right)$.

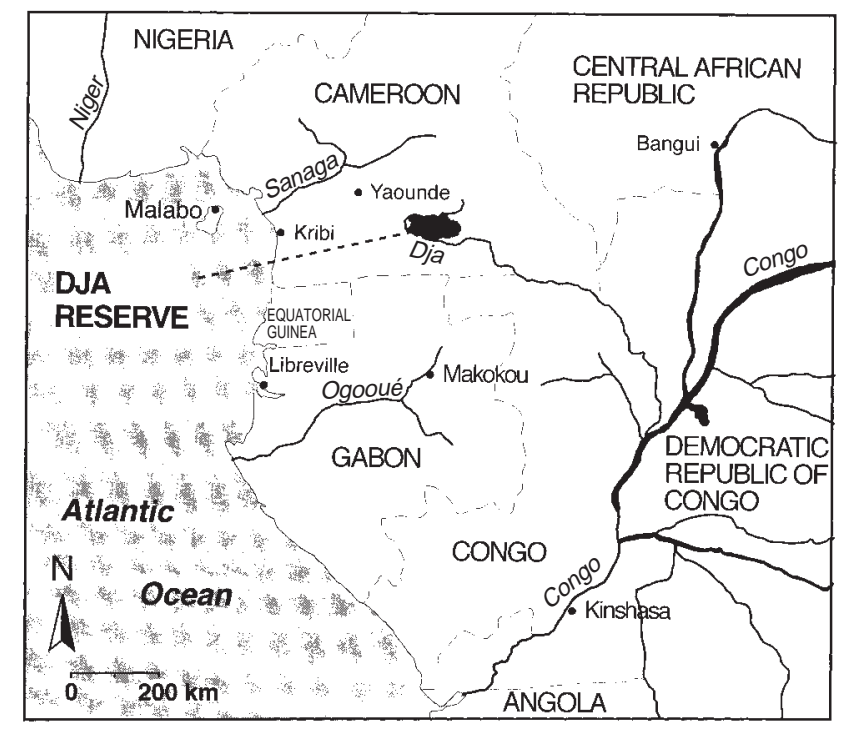

Fig. 1. Location of the Dja Reserve within the western Congo River basin. 
Table 1. Characterization of habitat types in the mature and secondary forest sites, Dja Reserve

\begin{tabular}{|c|c|c|c|}
\hline Habitat type & Extent $^{\mathrm{a}}$ & Dominant trees ${ }^{b}$ & Characteristics \\
\hline \multicolumn{4}{|c|}{ Mature forest site: Bouamir Research Station } \\
\hline Mature upland forest & $83 \cdot 0$ & $\begin{array}{l}\text { Desbordesia glaucescens } \\
\text { Uapaca paludosa } \\
\text { Terminalia superba }\end{array}$ & \\
\hline Inselberg-associated forest & $3 \cdot 3$ & $\begin{array}{l}\text { Lannea nigritiana } \\
\text { Celtis mildbraedii } \\
\text { Eribroma oblongum }\end{array}$ & $\begin{array}{l}\text { Distributed along edges of } \\
\text { inselberg grasslands }\end{array}$ \\
\hline $\begin{array}{l}\text { Raphia swamp } \\
\text { Uapaca } \text { swamp }\end{array}$ & $\begin{array}{l}6 \cdot 8 \\
6 \cdot 8\end{array}$ & $\begin{array}{l}\text { Raphia monbuttorum } \\
\text { Uapaca paludosa } \\
\text { Strombosiopsis tetranda } \\
\text { Berlinia } \mathrm{sp} .\end{array}$ & $\begin{array}{l}\text { Year-round inundation } \\
\text { Seasonal inundation }\end{array}$ \\
\hline \multicolumn{4}{|c|}{ Secondary forest site: Somalomo } \\
\hline Plantation & $22 \cdot 2$ & $\begin{array}{l}\text { Musanga cecropioides } \\
\text { Albizia sp. } \\
\text { Petersianthus macrocarpus }\end{array}$ & $\begin{array}{l}\text { Mosaic of cultivated fields } \\
(72 \%) \text { and young secondary } \\
\text { forest }(28 \%)\end{array}$ \\
\hline Young secondary forest & $31 \cdot 9$ & Musanga cecropioides & $\leq 30$ years in age \\
\hline Older secondary forest & $40 \cdot 4$ & - & $>30$ years in age \\
\hline Gilbertiodendron forest & $3 \cdot 4$ & Gilbertiodendron dewevrei & Monodominant stands \\
\hline Uapaca swamp & $2 \cdot 1$ & Uapaca paludosa & Seasonal inundation \\
\hline
\end{tabular}

${ }^{a}$ Extent $=$ percentage of the total area of each site. For the mature forest site, the relative extent of habitat types was determined through analysis of aerial photographs. Raphia swamp and Uapaca swamp are difficult to distinguish on photographs but were observed on the ground to be approximately equal in extent, thus, estimates were obtained by partitioning the observed swamp area equally between the two types. For the secondary forest site, analysis of older aerial photographs is not useful because of rapid habitat turnover. Instead, relative extent was estimated by the proportions occurring on animal survey transects.

${ }^{\mathrm{b}}$ Dominants in the mature forest site were determined from (27) $40 \times 40 \mathrm{~m}$ study plots (M. Fogiel, unpubl. data); dominants in the secondary forest site were determined by direct observation.

This area has never been commercially logged or farmed, has not been exploited for village agriculture in at least the past 90 years (J.-M. Froment, pers. comm.), and is $22 \mathrm{~km}$ from the nearest village or road. A feature unique to this site and a few other localities in the Reserve is the presence of inselbergs ('rochers'), outcroppings of rock characterized by shallow soils and grassland vegetation. Four main habitat types occur in this site: upland forest, Raphia swamp, Uapaca swamp, and inselbergassociated forest (see Table 1). Currently, 230 species of trees are known from the site (M. Fogiel, unpubl. data).

\section{Secondary forest site: Somalomo}

The secondary forest site is located in and surrounding the village of Somalomo $\left(3^{\circ} 22^{\prime} 24 " \mathrm{~N}, 12^{\circ} 43^{\prime} 53^{\prime \prime E}\right), 22$ $\mathrm{km}$ to the north of the Bouamir Research Station and just outside the Dja Reserve on the Dja River. This area is characterized by slash-and-burn agriculture, and is a mosaic of active plantations and regenerating forest. When mature forest is cleared for cultivation, some large trees are left (De Wachter, 1995); after abandonment, the site is dominated by a mix of these remaining trees and newly colonizing species, particularly Musanga cecropioides (Moraceae). We recognized four major habitat types in this site (Table 1): plantations (including coffee, cocoa and staple crops), young secondary forest ( $<30$ years), older secondary forest ( $>30$ years), and Gilbertiodendron forest. While Raphia and Uapaca swamps are also present at this site, they are not extensive and will not be considered further.

\section{Hornbill survey methods}

Hornbills were surveyed using modified line-transects, based on the distance sampling methods of Buckland et al., (1993). To avoid the disturbance associated with constructing a transect grid, surveys were carried out on a $25 \mathrm{~km}$ network of former hunting trails at the mature forest site, and on $18 \mathrm{~km}$ of plantation and hunting trails at the secondary forest site. Trails were mapped using a topofil distance measurer and compass, and were then subject to zonation into habitat types (see Table 1). Approximately $30 \mathrm{~km}$ of surveys were conducted every two weeks at the mature forest site from January to December 1994 (726 km total). Approximately $20 \mathrm{~km}$ of surveys were conducted monthly at the secondary forest site exclusive of January, August and October 1994 (177 km total).

Surveys were conducted between $06.00-11.00$ and $14.00-18.00$ by one researcher and one local guide working together. Trails were walked at a pace of approximately $2.5 \mathrm{~km} \mathrm{~h}^{-1}$; surveys were temporarily suspended during rainshowers. For each group of one or more hornbills encountered, the species, group size, observer-to-group distance, compass bearing of the trail, compass bearing of the group, time, and habitat type were recorded. Distances were estimated by eye to the nearest meter and were calibrated using an optical rangefinder. Observers occasionally left the trail to confirm group size, but all groups were initially detected from the transect line. 


\section{Density and biomass estimates}

Densities of hornbill groups were estimated from the transect data using the program DISTANCE (Laake et al., 1993), which implements the analysis described in Buckland et al. (1993). Time of day had no significant effect on the number of hornbill group sightings $\left(\chi^{2}=\right.$ 7.60, d.f. $=12, P=0.797$ for atrata groups; $\chi^{2}=14.95$, d.f. $=12, P=0.300$ for cylindricus groups; $\chi^{2}=6.40$, d.f. $=6, P=0.421$ for fistulator groups), so data from morning and afternoon surveys were pooled. Approximately $10 \%$ of the observations - those farthest from the transect line - were excluded from the analysis to improve model estimation (see Buckland et al., 1993), resulting in a truncated transect width of $325 \mathrm{~m}$. Densities of individuals were calculated as the product of group density and mean group size, where mean group sizes were based on a subset of the observations for which we were confident that all group members were counted. Calculation of standard errors of individual densities follows Raj (1968):

$$
\begin{gathered}
\mathrm{SE}(\text { individual density })=(\text { group density })^{2} \times \\
\mathrm{SE}(\text { group size })+(\text { group size })^{2} \\
\times \mathrm{SE}(\text { group density })+\mathrm{SE}(\text { group size }) \times \\
\mathrm{SE}(\text { group density })
\end{gathered}
$$

Hornbill densities in different habitats were compared using pairwise $z$ tests and a 0.05 significance level. Hornbill biomass was estimated using an average of the midpoints of mean adult male and female masses from Kemp (1995).

\section{Temporal patterns of fruit availability and hornbill abundance}

Fruit availability at the mature forest site was measured using the raked-trail survey method (Sabatier, 1985; Zhang \& Wang, 1995). Fruit falling onto a $4.3 \mathrm{~km}, 1 \mathrm{~m}$ wide trail was surveyed biweekly. For each fruit patch (produced by an individual tree or liana) encountered on the trail, the species and the approximate numbers of ripe and unripe fruits were recorded. The trail was then cleared so that the fruits would not be counted on the next sampling date. Fruits of understory and of winddispersed species were uncommon and were not recorded. While not randomly placed, the trail sampled habitats in rough proportion to habitat abundance; mature forest, swamp, and inselberg habitats represented $75.4,23.3$, and $1.3 \%$ of the raked trail and 83.0, 13.7, $3.3 \%$ of the site, respectively. Two monthly indices of fruit availability are employed to represent the rakedtrail results: 'number of individuals in fruit' is the number of all fruit patches found on the trail, and 'number of species in fruit' is the number of species comprising those individuals. Measurements of fruit availability were not made at the secondary forest site, where they likely would have been compromised by human foot traffic.

Monthly abundance indices of hornbills were determined from the transect data in the following manner: for each sampling period, all hornbill groups encountered within $100 \mathrm{~m}$ of the transect line were tabulated (thus transect width was set at $200 \mathrm{~m}$ ), and this number was multiplied by the mean monthly group size to determine the number of individuals encountered. The monthly abundance indices are expressed as individual birds encountered per $100 \mathrm{~km}$. Temporal patterns of hornbill abundance were compared using the Pearson correlation coefficient and single-factor ANOVA $(\alpha=0 \cdot 05)$.

Indices of hornbill abundance and fruit availability in the mature forest site were compared using regression. To determine if relationships remained significant after accounting for possible temporal autocorrelation (Verdú \& García-Fayos, 1994), simple and partial Mantel tests were employed using the ' $R$ ' Package (Legendre \& Vaudor, 1991). Mantel tests were carried out using 1000 permutations of the matrices.

\section{RESULTS}

\section{Hornbill densities, biomass and habitat use}

Six of the seven species in the hornbill assemblage of the Dja Reserve (all but $T$. hartlaubi) were recorded frequently enough to allow density estimations. Densities of these species in the mature and secondary forest sites ranged from 0.6 to 13.3 birds $\mathrm{km}^{-2}$, and overall hornbill assemblage biomass was estimated at 20.0 and $27.3 \mathrm{~kg}$ $\mathrm{km}^{-2}$ for the mature and secondary forest sites, respectively (Table 2).

\section{Between-site habitat preferences: mature vs. secondary forest}

Each of the three Ceratogymna species showed significant differences in usage of the mature and secondary forest sites, while none of the three Tockus species did so (Table 2). Densities of atrata were significantly higher in the mature forest site than in the secondary forest site. In contrast, both cylindricus and fistulator densities were significantly lower in the mature forest site compared with the secondary forest site. Overall, the hornbill assemblage reached a higher density in the secondary forest site $\left(30.9\right.$ birds $\left.\mathrm{km}^{-2}\right)$ than in the mature forest site $\left(20 \cdot 2\right.$ birds $\left.\mathrm{km}^{-2}\right)$.

\section{Within-site habitat preferences}

Sample sizes were large enough to analyze within-site habitat preferences for atrata and cylindricus, but not for other hornbill species. At the mature forest site, atrata reached significantly higher densities in inselbergassociated forest than in any other habitat type ( $z$ test, $P \leq 0.036$ in all comparisons; Table 3). There was no significant preference apparent in their use of upland forest, Uapaca swamp, and Raphia swamp habitats. In the secondary forest site, atrata densities were not significantly different between habitat types, with the exception of Gilbertiodendron forests in which no atrata individuals were ever recorded. 
Table 2. Comparison of hornbill assemblages in the mature and secondary forest sites, Dja Reserve, 1994. Densities are given \pm SEM.

\begin{tabular}{|c|c|c|c|c|c|c|c|c|}
\hline \multirow[b]{2}{*}{ Species } & \multirow[b]{2}{*}{$\begin{array}{r}\text { Mass } \\
(\mathrm{kg})^{\mathrm{a}}\end{array}$} & \multicolumn{3}{|c|}{$\begin{array}{c}\text { Mature forest site } \\
\text { (Bouamir Research Station) }\end{array}$} & \multicolumn{3}{|c|}{$\begin{array}{l}\text { Secondary forest site } \\
\text { (Somalomo) }\end{array}$} & \multirow[b]{2}{*}{$P^{\mathrm{b}}$} \\
\hline & & $n$ & $\begin{array}{c}\text { Density } \\
\text { (indiv. } \mathrm{km}^{-2} \text { ) }\end{array}$ & $\begin{array}{l}\text { Biomass } \\
\left(\mathrm{kg} \mathrm{km}^{-2}\right)\end{array}$ & $n$ & $\begin{array}{c}\text { Density } \\
\text { (indiv. } \mathrm{km}^{-2} \text { ) }\end{array}$ & $\begin{array}{l}\text { Biomass } \\
\left(\mathrm{kg} \mathrm{km}^{-2}\right)\end{array}$ & \\
\hline Ceratogymna atrata & $1 \cdot 20$ & 647 & $8 \cdot 7 \pm 0.6$ & $10 \cdot 5$ & 89 & $5 \cdot 7 \pm 1 \cdot 0$ & $6 \cdot 9$ & $0.008 * *$ \\
\hline C. cylindricus & $1 \cdot 13$ & 286 & $7 \cdot 2 \pm 1 \cdot 0$ & $8 \cdot 1$ & 147 & $13 \cdot 3 \pm 1 \cdot 8$ & $15 \cdot 0$ & $0.004 * *$ \\
\hline C. fistulator & 0.55 & 36 & $1.4 \pm 0.4$ & 0.7 & 55 & $8.1 \pm 1.9$ & 4.5 & $0.001 * *$ \\
\hline Tockus albocristatus & $0 \cdot 31$ & 39 & $0.7 \pm 0.2$ & $0 \cdot 2$ & 10 & $0.6 \pm 0.2$ & $0 \cdot 2$ & 0.536 \\
\hline T. fasciatus & $0 \cdot 26$ & 78 & $1 \cdot 2 \pm 0 \cdot 3$ & $0 \cdot 3$ & 29 & $2.5 \pm 0.7$ & 0.7 & 0.083 \\
\hline T. camurus & $0 \cdot 10$ & 92 & $1 \cdot 0 \pm 0 \cdot 2$ & $0 \cdot 1$ & 21 & $0 \cdot 6 \pm 0 \cdot 2$ & $0 \cdot 1$ & $0 \cdot 178$ \\
\hline T. hartlaubi & $0 \cdot 10$ & 3 & - & - & 0 & - & - & \\
\hline Totals & & & $20 \cdot 2$ & $20 \cdot 0$ & & $30 \cdot 9$ & $27 \cdot 3$ & \\
\hline
\end{tabular}

a Mean body masses are based on the midpoint of mean adult male mass and mean adult female mass from Kemp (1995).

${ }^{b} P$-value of $z$ test for whether densities are similar in the mature and secondary forest sites.

** $P<0.01$.

$n$, number of hornbill groups encountered in surveys. Models used in density estimation were: uniform (C. fistulator and T. camurus in mature forest, T. albocristatus in secondary forest), composite models (C. atrata and C. cylindricus, see Table 3) and half-normal (all other estimates).

Table 3. Densities ( \pm SEM) of C. atrata and C. cylindricus by habitat. Site averages are area-weighted averages (see Table 1$)$.

\begin{tabular}{|c|c|c|c|c|c|c|}
\hline \multirow[b]{2}{*}{ Site / habitat } & \multicolumn{3}{|c|}{ C. atrata } & \multicolumn{3}{|c|}{ C. cylindricus } \\
\hline & $n$ & groups $\mathrm{km}^{-2}$ & indiv. $\mathrm{km}^{-2}$ & $n$ & groups $\mathrm{km}^{-2}$ & indiv. $\mathrm{km}^{-2}$ \\
\hline \multicolumn{7}{|c|}{ Mature forest site: Bouamir Research Station } \\
\hline $\begin{array}{l}\text { Mature upland forest } \\
\text { Inselberg-associated forest } \\
\text { Raphia } \text { swamp } \\
\text { Uapaca } \text { swamp }\end{array}$ & $\begin{array}{r}443 \\
108 \\
37 \\
59\end{array}$ & $\begin{array}{l}4 \cdot 3 \pm 0 \cdot 3 \\
8 \cdot 3 \pm 1 \cdot 3 \\
4 \cdot 8 \pm 1 \cdot 0 \\
3 \cdot 3 \pm 0 \cdot 6\end{array}$ & $\begin{array}{r}8 \cdot 5 \pm 0 \cdot 7 \\
16 \cdot 5 \pm 2 \cdot 7 \\
9 \cdot 5 \pm 2 \cdot 0 \\
6 \cdot 5 \pm 1 \cdot 2\end{array}$ & $\begin{array}{r}201 \\
66 \\
6 \\
13\end{array}$ & $\begin{array}{l}2 \cdot 6 \pm 0 \cdot 3 \\
5 \cdot 4 \pm 1 \cdot 1 \\
0 \cdot 5 \pm 0 \cdot 2 \\
1 \cdot 2 \pm 0 \cdot 4\end{array}$ & $\begin{aligned} 7 \cdot 6 & \pm 1 \cdot 1 \\
16 \cdot 0 & \pm 3 \cdot 4 \\
1 \cdot 5 & \pm 0 \cdot 5 \\
3 \cdot 6 & \pm 1 \cdot 3\end{aligned}$ \\
\hline Site average & & $4 \cdot 4 \pm 0 \cdot 3$ & $8 \cdot 7 \pm 0 \cdot 6$ & & $2 \cdot 4 \pm 0 \cdot 3$ & $7 \cdot 2 \pm 1 \cdot 0$ \\
\hline \multicolumn{7}{|c|}{ Secondary forest site: Somalomo } \\
\hline $\begin{array}{l}\text { Plantation } \\
\text { Young secondary forest } \\
\text { Older secondary forest } \\
\text { Gilbertiodendron forest }\end{array}$ & $\begin{array}{r}16 \\
42 \\
31 \\
0\end{array}$ & $\begin{array}{c}2 \cdot 2 \pm 0 \cdot 6 \\
3 \cdot 5 \pm 0 \cdot 8 \\
2 \cdot 5 \pm 0 \cdot 7 \\
0 \cdot 0\end{array}$ & $\begin{array}{l}4 \cdot 5 \pm 1 \cdot 4 \\
7 \cdot 3 \pm 1 \cdot 7 \\
5 \cdot 3 \pm 1 \cdot 4 \\
0 \cdot 0\end{array}$ & $\begin{array}{r}74 \\
62 \\
11 \\
0\end{array}$ & $\begin{array}{c}10 \cdot 0 \pm 1 \cdot 9 \\
8 \cdot 1 \pm 1 \cdot 6 \\
1 \cdot 1 \pm 0 \cdot 4 \\
0 \cdot 0\end{array}$ & $\begin{aligned} & 22 \cdot 1 \pm 4 \cdot 3 \\
& 17 \cdot 8 \pm 3 \cdot 6 \\
& 2 \cdot 5 \pm 1 \cdot 0 \\
& 0 \cdot 0\end{aligned}$ \\
\hline Site average & & $2 \cdot 8 \pm 0 \cdot 4$ & $5 \cdot 7 \pm 1 \cdot 0$ & & $6 \cdot 0 \pm 0 \cdot 8$ & $13 \cdot 3 \pm 1 \cdot 8$ \\
\hline
\end{tabular}

$n$, number of hornbill groups encountered in surveys. Models used in estimation were the: half-normal (cylindricus in mature upland forest, Uapaca swamp and young secondary forest), hazard rate (atrata in Uapaca swamp, cylindricus in inselberg-associated forest and plantation), and uniform (all other estimates).

In the mature forest site, cylindricus showed a pattern similar to atrata, with higher densities in inselbergassociated forest than in any other habitat type ( $z$ test, $P \leq 0.020$ in all comparisons; Table 3). However, unlike atrata, cylindricus densities were significantly higher in upland forest compared with either Uapaca swamp or Raphia swamp ( $z$ test, $P=0.019$ and 0.001, respectively). In the secondary forest site, cylindricus showed no significant difference in its use of plantation and young secondary forest habitats. However, densities were significantly lower in older secondary forest than in either of the younger habitats $(z$ test, $P<0.001$ in both comparisons). No cylindricus were ever recorded in Gilbertiodendron forests.

\section{Fruit availability}

Over 350 individuals of 102 species of fruiting trees and lianas were recorded during the raked-trail survey at the mature forest site. Of these, at least 10 species (represented by 29 individuals on the trail) are consumed by Ceratogymna hornbills (Whitney et al., 1998). General trends in fruit production by the tree and liana community were well represented by two indices, the number of individuals in fruit and the number of species in fruit (Fig. 2). The two indices were highly correlated (Pearson's $r=$ $0.875 ; P<0.001)$. When measured by either index, fruit availability was lowest from January to April, and highest from May to December (no. individuals in fruit, $F=32.98$, d.f. $=1,23, \mathrm{P}<0.001$; no. species in fruit, $F=39.77$, d.f. $=1,23, P<0.001)$. When compared to rainfall during the same month or during either of the two previous months, both indices were most closely correlated with rainfall one month previous, although correlations did not reach statistical significance (no. individuals in fruit, $r=0.429, P$ $=0.164$; no. species in fruit, $r=0.516, P=0.086$ ). 


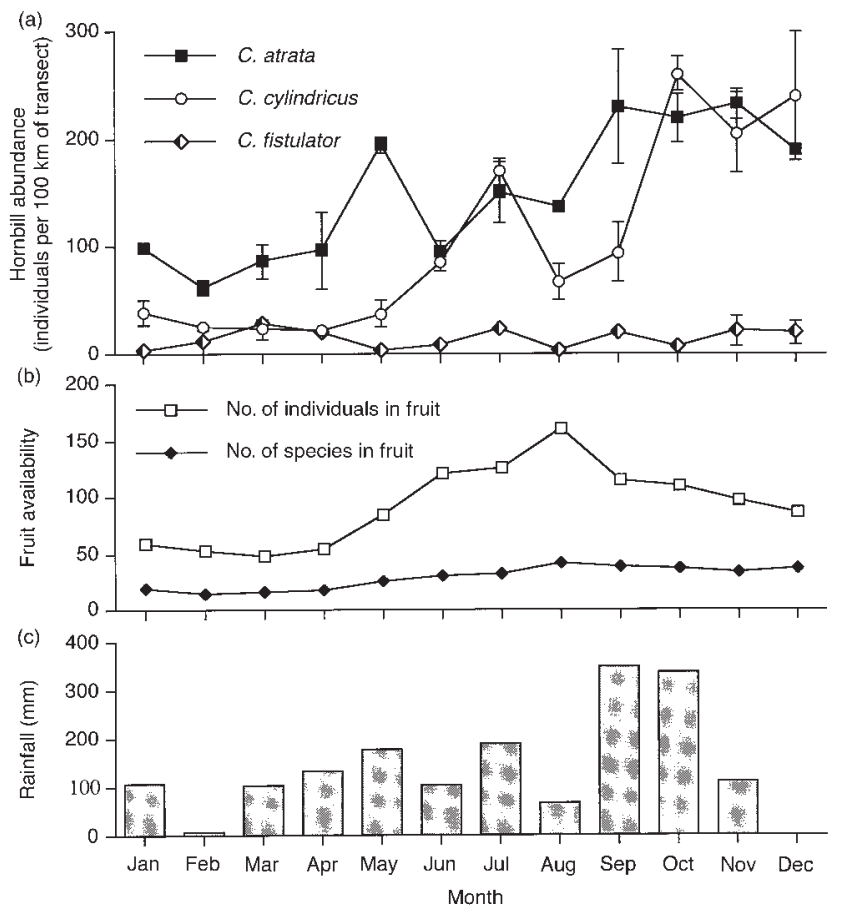

Fig. 2. Temporal patterns of hornbill abundance, fruit availability, and rainfall at the mature forest site, 1994. (a) Monthly hornbill abundance indices (individuals per $100 \mathrm{~km}$ of transect \pm SEM). When standard errors are very small, error bars do not appear. (b) Community fruit availability measured on a $4.3 \mathrm{~km}$ trail. (c) Monthly rainfall $(\mathrm{mm})$.

\section{Hornbill responses to fruit availability}

Monthly abundances (birds per $100 \mathrm{~km}$ of transect) of both atrata and cylindricus were highly variable at the mature forest site (Fig. 2). Ceratogymna atrata abundances varied nearly four-fold, while cylindricus abundances varied 12-fold. This contrast between peaks and valleys of abundance is consistent with a scenario in which as much as 74 and $92 \%$ of the atrata and cylindricus populations, respectively, leave the study area on a seasonal basis. Sightings throughout the year of a cylindricus individual with distinctive plumage markings indicate that populations do not turnover completely, however. Both species were less abundant from January through April, and more abundant from May to December (atrata, $F=22 \cdot 19$, d.f. $=1,22, P<0.001$; cylindricus, $F=13.53$, d.f. $=1,22, P=0.001)$, reaching peaks in October (atrata) and November (cylindricus). Monthly abundances of atrata and cylindricus at the mature forest site were highly correlated $(r=0.699, P$ $=0 \cdot 011$ ). These results suggest that the two species respond similarly to fruit production and/or other temporal factors affecting abundance.

During 1994, the monthly availability of fruit was a good predictor of atrata and cylindricus abundances in the mature forest site. Abundances of atrata and cylindricus were each significantly positively related to both the number of fruiting species and the number of fruiting individuals (Table 4). Analysis using partial Mantel tests found that the relationships between fruit availability and atrata and cylindricus abundances remained significant or nearly significant after controlling for temporal autocorrelation $(P<0.05$ in all comparisons except atrata $v s$. fruiting individuals for which $P=$ 0.139; Table 4).

In contrast to atrata and cylindricus responses, fistulator showed no significant population response to fruit availability. Abundances were fairly constant throughout the year at the both the mature and secondary forest sites (Figs 2 and 3); January-April and May-December abundances were not significantly different within either site (mature forest, $F=0.25$, d.f. $=1,22, P=0.624$; secondary forest, $F=1 \cdot 13$, d.f. $=1,30, P=0 \cdot 296$ ). Regression analysis found no significant relationship between either index of fruit availability and fistulator abundance at the mature forest site (Table 4).

\section{Between-site synchrony in hornbill abundances}

To look for evidence that Ceratogymna hornbills may make large-scale seasonal movements, we examined the synchrony of hornbill abundances in the mature and secondary forest sites, which are separated by $22 \mathrm{~km}$. As with responses to fruit availability, atrata and cylindricus show one pattern, while fistulator shows another (Fig. 3). Ceratogymna atrata and cylindricus abundances at the mature forest site were significantly and

Table 4. Results of regression analysis and partial Mantel tests of monthly fruit availability and hornbill abundances in the mature forest site, 1994. Bird and fruit data were log-transformed prior to analysis. Mantel's $r$ is standardized.

\begin{tabular}{|c|c|c|c|c|c|}
\hline \multirow[t]{2}{*}{ Index of fruit availability } & \multirow[t]{2}{*}{ Hornbill species } & \multicolumn{2}{|c|}{ Regression } & \multicolumn{2}{|c|}{ Mantel test ${ }^{\mathrm{a}}$} \\
\hline & & $r^{2}$ & $P$ value & Mantel's $r$ & $P$ value \\
\hline \multirow[t]{3}{*}{ Number of species in fruit } & C. atrata & $0 \cdot 66$ & $0 \cdot 001^{*}$ & $0 \cdot 96$ & $0.012 *$ \\
\hline & C. cylindricus & $0 \cdot 69$ & $0.001 *$ & $0 \cdot 68$ & $0.016^{*}$ \\
\hline & C. fistulator & $0 \cdot 00$ & $0.858^{*}$ & $-0 \cdot 17$ & $0 \cdot 329$ \\
\hline \multirow[t]{3}{*}{ Number of individuals in fruit } & C. atrata & $0 \cdot 36$ & $0.037 *$ & 0.29 & $0 \cdot 139$ \\
\hline & C. cylindricus & 0.49 & $0.011^{*}$ & 0.62 & $0.032 *$ \\
\hline & C. fistulator & 0.03 & $0.595^{*}$ & -0.07 & 0.470 \\
\hline
\end{tabular}

a Significant results indicate that monthly bird abundance remains significantly predicted by fruit availability after controlling for temporal autocorrelation.

$* P<0.05$. 
positively correlated with their abundances at the secondary forest site (atrata, $r=0.659, P=0.053$; cylindricus, $r=0.834, P=0.005)$. This evidence is consistent with movements on a regional scale, and suggests that populations of these species perceive the mature and secondary forest sites as part of the same resource patch. Ceratogymna fistulator abundances showed no such correlation between sites (Fig. $3 ; r=0.163 ; P=0.676$ ), corroborating evidence (see above) that this species does not track fruit availability via large-scale movements.

\section{DISCUSSION}

\section{Hornbill densities, biomass and habitat use}

One possible source of bias in transect sampling of hornbills is related to their cavity-nesting habit. Because nesting females are walled into their nesting cavities for several months, density estimates may be biased low during nesting periods. However, extensive searches and monitoring of previously used cavities determined that no breeding occurred in the mature and secondary forest sites during 1994, and thus this source of error is not applicable. Another source of bias that does apply is related to the use of non-linear transects. Foot trails, such as those used in the present study, are useful for sam-
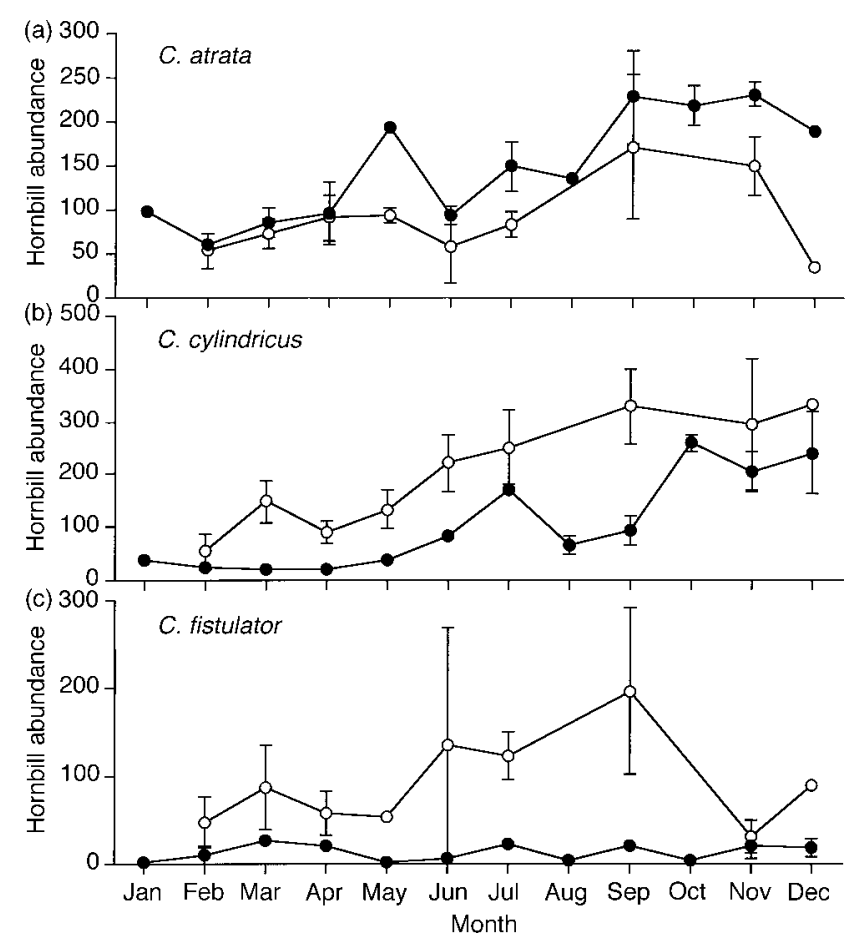

Fig. 3. Comparison of hornbill abundances in the mature forest $(\bullet)$ and secondary forest (०) sites, 1994. These sites are separated by $22 \mathrm{~km}$ of mature forest. Monthly abundance indices (individuals per $100 \mathrm{~km}$ of transect) are \pm SEM; when standard errors are very small, error bars do not appear. The December estimates in secondary forest are based on a single sample. (a) C. atrata $(r=0.659 ; P=0.053)$. (b) C. cylindricus $(r=0.834, P=0.005)$. (c) C. fistulator $(r=0.163, P=$ $0 \cdot 676)$. pling volant or arboreal species whose movements and habitat use are not likely to be affected by terrestrial trails. Several studies have successfully used hunting trails (Thomas, 1991), other types of non-linear, nonrandom trails (Defler \& Pintor, 1985) or even roads (Skorupa, 1988) as transects. However, non-linear transects underestimate density because the estimated sampling area is greater than the actual area sampled (J. L. Laake, pers. comm.). For this reason, density estimates presented in this study should be treated as conservative.

Frugivore assemblage biomasses are useful in comparisons among different sites, and potentially will be useful in assessing the impacts of different groups on seed dispersal once more data become available. To date, this is the only known study to estimate the densities and biomass of an African hornbill assemblage. Kalina (1988) studied C. subcylindricus in the Kibale Forest, Uganda, and while biomass of the other species ( $T$. alboterminatus) in the two-species hornbill assemblage was not established, biomass of subcylindricus ranged from 16.7 to $36.2 \mathrm{~kg} \mathrm{~km}^{-2}$. Elsewhere in the Old World tropics, hornbill assemblage biomass ranges from 8.6 to $121.7 \mathrm{~kg} \mathrm{~km}^{-2}$ (Kinnaird et al., 1996). Our estimate of the biomass of the Dja hornbill assemblage (20.0-27.3 $\mathrm{kg} \mathrm{km}^{-2}$ ) thus falls within the known ranges from other sites.

\section{Between-site habitat preferences: mature vs. secondary forest}

While densities of Tockus hornbills were not significantly different between sites, there is a clear divergence in habitat preferences of Ceratogymna species in the Dja Reserve. Ceratogymna atrata reaches its highest densities in mature forest habitats, while cylindricus and fistulator attain their highest densities in secondary forests associated with village agriculture. These differences may be related to differences in hunting pressures, differences in nest cavity abundance and size, and/or differences in vegetation composition (which in turn determine food availability).

Hunting is unlikely to be a factor in generating the observed patterns of hornbill densities. Relative to other game species, hunters in the Dja region rarely take Ceratogymna hornbills (K. Whitney, pers. obs.). The overall density of Ceratogymna hornbills is higher in the secondary forest site, where hunting for all animal species is much more intense, than in the mature forest site (Table 2).

Populations of many cavity-nesting species are subject to nest-site limitation (Wiens, 1989), and hornbill populations are likely to be limited in this way (Kemp, 1995). The availability of suitable hornbill nesting cavities may differ between logged and unlogged habitats because of differences in the abundance of largediameter trees (Kalina, 1988). It may be that cylindricus and fistulator, which are smaller in size than atrata, are able to use smaller trees for nesting. The availability of suitable nest cavities in the mature and secondary forest 
sites is unknown, and thus we cannot evaluate potential nesting habitat effects on hornbill densities. However, it is important to note that the observed habitat preferences occurred in a non-nesting year, indicating that differences in fruit resources may play a more important role in generating the observed patterns.

Vegetation composition of the mature and secondary forest sites has not been directly contrasted. However, De Wachter (1995) characterized similar mature forests and plantations near Ekom, $34 \mathrm{~km}$ to the west of the Somalomo secondary forest site. He found that cultivated fields retained $4.5 \%$ of the number of smaller stems $(10-70 \mathrm{~cm} \mathrm{dbh})$ and $57 \%$ of the larger stems (>70 $\mathrm{cm} \mathrm{dbh}$ ) found in mature forest. This pattern occurs because farmers do not cut all trees when preparing a plantation site. Large-diameter trees, especially those with hard woods, are left standing in cultivated fields because of the difficulty in felling them. These trees persist in the regenerating forest after cultivation is abandoned. De Wachter (1995) lists the 22 tree species most frequently left standing in Dja plantations; fruits from five of these (Ficus sp., Pycnanthus angolensis, Xylopia sp., Margaritaria discoidea and Cleistopholis patens) are consumed by at least one Ceratogymna species (Whitney et al., 1998). Thus, a subset of the fruit resources available to hornbills in mature forest is also available in these secondary forest habitats. Unique fruit resources are available in secondary forest as well. Musanga cecropioides and Ficus exasperata are rare in mature forest, but are common in regenerating forest. Ficus exasperata is planted in cocoa plantations in the Dja region as a shade species (De Wachter, 1995). These species and others in the Moraceae were major sources of food for cylindricus and fistulator in the secondary forest site in 1994 (K. Whitney, unpubl. data). Our observations are in accord with other data suggesting that figs are often rare in mature forests but common in secondary forests in Africa (Gautier-Hion \& Michaloud, 1989).

The observed habitat-use patterns of Ceratogymna hornbills are thus consistent with species-specific responses to differing fruit resources in the mature and secondary forest sites. Whether nest-site availability differs between these two habitats, and whether it contributes to hornbill habitat-use patterns, remain to be elucidated. Because secondary forests are created by multiple mechanisms, work is needed to refine our understanding of hornbill responses to habitat disturbance. Because of the agricultural practice of leaving large trees, secondary forests produced by shifting agriculture (including those in this study) are probably much different than secondary forests produced by logging, in which large hardwoods are selectively removed. Hornbill populations are likely to respond differently to these two types of secondary forest, and the high hornbill densities found in village-associated secondary forest in this study are not a guarantee that similar densities would be supported in logged forests. So far, data on the effects of selective logging on hornbill densities are ambiguous. In Uganda, Kalina (1988) compared two unlogged plots with one logged plot and found that $C$. subcylindricus densities were equal in one logged and one unlogged plot, while higher in the other unlogged plot. In Malaysia, Johns (1987) and Lambert (1992) observed little change in abundances of several hornbill species following selective logging, but small sample sizes make interpretation difficult.

\section{Within-site habitat preferences}

Ceratogymna cylindricus was observed to have relatively low densities in Raphia swamp habitats (Table 3). Raphia monbuttorum is a palm which produces large (4-6 cm long) drupes. Although cylindricus is known to occasionally take Raphia fruits (Whitney et al., 1998), the species may be restricted to only the smallest fruits. In terms of fruit resources, there is little else in this habitat to attract cylindricus.

Inselberg-associated forest was heavily utilized by Ceratogymna hornbills. This forest has a distinct composition and contains species of hornbill feeding trees which are rare elsewhere; in particular, Lannea welwitschii, Eribromum oblongum, and Maesopsis eminii reach high basal areas within $20 \mathrm{~m}$ of the grassland-forest interface but are not well represented in any other habitat types at the mature forest site (M. Fogiel, unpubl. data). One of these inselberg-associated species in particular, Lannea welwitschii, produced abundant fruit from early June to mid-September 1994 and was heavily fed upon by Ceratogymna hornbills. Inselbergassociated forest comprises only $3 \%$ of the mature forest site and is even less frequent in the Dja Reserve as a whole. Further work on the role of this habitat type in influencing hornbill movements and distribution would be valuable.

Gilbertiodendron forests are monodominant stands of $G$. dewevrei (Caesalpinioideae), which mast fruits at intervals of two to three years (Hart, 1995). G. dewevrei was not observed to fruit during 1994; furthermore, its fruits are large woody pods and are unlikely to be eaten by hornbills. It is thus of little surprise that no hornbills of any species were recorded in these forests.

\section{Resource tracking and large-scale movements}

This study provides the first empirical evidence for resource tracking and large-scale movements by African hornbills. The larger species occurring in the Dja Reserve, atrata and cylindricus, track fruit resources through seasonal emigrations and show synchronous population fluctuations in distant sites. Perhaps as much as three-quarters of their populations are involved. The spatial scale of their movements remains to be determined, as does whether their movements represent true seasonal migrations, or nomadism. In any case, previous characterizations of these species as 'resident' (Fry et al., 1988; Dowsett \& Dowsett-Lemaire, 1993; Christy, 1994) with fixed home ranges of 150 to 'several hundred' hectares (Brosset \& Erard, 1986) are not supported by the data. A smaller species, fistulator, does not track 
fruit resources (at least, not on the same scale as its congeners) and does not exhibit between-site synchrony in abundance, indicating that it is relatively sedentary. These patterns may be related to the degree of frugivory among the three species. While all are highly frugivorous, fistulator is less so than the other two species (Whitney et al., 1998).

Where do atrata and cylindricus hornbills from the Dja go during the early part of the year? Although fruit resources can change substantially over short distances $(<10 \mathrm{~km})$, it is interesting to note that drastically different rainfall regimes (and by logical extension, fruit production regimes) occur within a few hundred kilometers of the Dja Reserve. To the west, rainfall increases and becomes unimodal in its yearly distribution; by Kribi $(300 \mathrm{~km}$ from the Dja and on the Atlantic coast, see Fig. 1), the annual rainfall of $3000 \mathrm{~mm}$ is twice that of the Dja and has a single peak in August (Laclavère, 1980). To the south, rainfall remains bimodal, but by Makokou (250 km from the Dja and in Gabon) the major and minor dry seasons are reversed (comparison of data from Laclavère, 1980, and from Gautier-Hion et al., 1985). Smith (1990) suggested that such regional differences in rainfall might be the cause of the likely seasonal migrations of some forest granivores in Cameroon. Documentation of regional fruit and frugivore abundance patterns in the Afrotropics is an important area of future study.

Wandering movements, perhaps in response to fruit availability, have been anecdotally recorded for African hornbill species of patchy habitats. In montane forests in Malawi, C. brevis and C. bucinator both show long-range movements; brevis in particular has been noted in forest patches over $100 \mathrm{~km}$ from breeding areas (DowsettLemaire, 1989). The same two species apparently range widely in patchy woodland, coastal, and riparian habitats in East Africa (Britton, 1980). However, resource tracking and large-scale movements have never before been demonstrated for lowland, continuous-forest hornbill species in Africa. These new results are consistent with the movements of several Asian hornbill species. On Borneo, Leighton \& Leighton (1983) found large seasonal fluctuations in the densities of Rhyticeros hornbills and other frugivores; emigrations from their site were related to food-lean periods. Populations of Aceros undulatus are nomadic, frequently crossing stretches of open water including that between Bali and Java (Kemp, 1995). On Sulawesi, Kinnaird et al. (1996) found that fig fruit densities predicted abundances and flock sizes of Sulawesi red-knobbed hornbills (Aceros cassadix). The scarcity of observations suggesting large-scale movements by African hornbills of the forest block may be related less to biological fact than to the difficulties in studying vagile species in continuous lowland forests.

\section{Conservation implications}

The current study has several implications for conservation of Central African Ceratogymna hornbills and their lowland forest habitats. First, if current trends in the disappearance of more vulnerable seed dispersers (e.g. forest elephants, Loxodonta africana cyclotis, and primates) continue, hornbills are likely to play increasingly larger roles in the dynamics of forest regeneration. Because elephants, primates, and hornbills disperse substantially different groups of species (Whitney et al., 1998), changes in forest composition over the long term are possible, potentially in the direction of increased presence of hornbill-dispersed species.

Second, the results show that Ceratogymna hornbills are active in seed dispersal in both mature and secondary forests. As the forest block becomes increasingly fragmented, an important question is whether hornbill seed dispersal will continue to contribute to regeneration in isolated forest patches. To reach such patches, hornbills would have to travel through a matrix of degraded habitat, including plantations, open space, and urban areas. Hornbill species of naturally patchy habitats apparently regularly cross inhospitable areas (e.g. East African Ceratogymna species; Britton, 1980; Dowsett-Lemaire, 1989), but further work is needed to understand whether and when lowland, continuous-forest species (such as atrata and cylindricus) will cross matrix areas.

Finally, that lowland, continuous-forest hornbill species make unsuspected large-scale movements is intriguing, and adds credence to speculation (Thomas, 1983; Thiollay, 1985; Fleming et al., 1987) that nomadic or migratory movements of paleotropical frugivores may be more extensive than previously thought. Confirmation that other large seed dispersers make large-scale movements would require us to rethink our approach to the conservation of central African forests (for a related situation in the Neotropics, see Powell \& Bjork, 1994, 1995). The effective design and management of a system of reserves would need to take into account both how the reserves are connected, and the seasonal and spatial patterns of fruit production necessary for sustaining disperser populations.

\section{Acknowledgements}

We are grateful to the government of the Republic of Cameroon, in particular the Ministry of Environment and Forests (MINEF) and the Ministry of Higher Education and Scientific Research (MINREST), for permission to conduct this research. In particular we wish to thank J. Mengang, J.-P. Boyogueno and V. Balinga. Financial and logistical support were generously provided by NYZS/The Wildlife Conservation Society, the National Science Foundation Graduate Fellowship Program, San Francisco State University, and ECOFAC Cameroun. The NSF GRT Program of UC Davis and SFSU is acknowledged for support during data analysis. For long hours in the field we thank D. Amazieh, B. Bokama, B. Demarest, E. Hekkala, M. Russell, R. Rynning, J. Schuetz, A. Siec, A. Smyth and J. Witkin. V. T. Parker, E. Routman and two anonymous reviewers provided helpful comments on the manuscript. This work would not have been possible without the help of J.-M. Froment, T. \& H. Hockey, R. Fotso, A. Smyth and especially M. Fogiel. 


\section{REFERENCES}

Bierregaard, R. O. J. \& Lovejoy, T. E. (1988). Birds in Amazonian forest fragments: effects of insularization. In Acta XIX congressus internationalis ornithologici: 1564-1579. Ouillet, H. (Ed.). Ottawa: University of Ottawa Press.

Bond, W. J. \& Slingsby, P. (1984). Collapse of an ant-plant mutualism: the Argentine ant (Iridomyrmex humilis) and myrmecochorous Proteaceae. Ecology 65: 1031-1037.

Britton, P. L. (Ed.) (1980). Birds of East Africa: their habitat, status, and distribution. Nairobi: East African Natural History Society.

Brosset, A. \& Erard, C. (1986). Les oiseaux des régions forestières du nord-est du Gabon. Vol. 1: Écologie et comportement des espèces. Revue d'Écologie (Terre et Vie) Suppl. 3.

Buckland, S. T., Anderson, D. R., Burnham, K. P. \& Laake, J. L. (1993). Distance sampling: estimating abundance of biological populations. London: Chapman \& Hall.

Christy, P. (1994). Inventaire ornithologique de la Réserve de la Faune du Dja. Rapport Intermédiaire. Yaoundé, Cameroun: Projet ECOFAC, Composante Cameroun.

Defler, T. R. \& Pintor, D. (1985). Censusing primates in a forest of known primate density. Int. J. Primatology 6: 243-259.

De Wachter, P. (1995). Agriculture itinérante badjoué dans la Réserve de Faune du Dja (Est-Cameroun). Travail de fin d'études. Leuven: Katholieke Universiteit Leuven.

Dowsett, R. J. \& Dowsett-Lemaire, F. (1993). A contribution to the distribution and taxonomy of Afrotropical and Malagasy birds. Tauraco Res. Rep. 5: 1-389.

Dowsett-Lemaire, F. (1989). Ecological and biogeographical aspects of forest bird communities in Malawi. Scopus 13: 1-80.

Fleming, T. H. (1992). How do fruit- and nectar-feeding birds and mammals track their food resources? In Effects of resource distribution on animal-plant interactions: 355-391. Hunter, M. D., Ohgushi, T. \& Price, P. W. (Eds). San Diego: Academic Press.

Fleming, T. H., Breitwisch, R. \& Whitesides, G. H. (1987). Patterns of tropical vertebrate frugivore diversity. Ann. Rev. Ecol. Syst. 18: 91-109.

Foster, R. B. (1982). Famine on Barro Colorado Island. In The ecology of a tropical forest: seasonal rhythms and long-term changes: 201-212. Leigh, E. G., Rand, A. S. \& Windsor, D. S. (Eds). Washington, DC: Smithsonian Press.

Fry, C. H., Keith, S. \& Urban, E. K. (Eds). (1988). The birds of Africa, volume III. London: Academic Press.

Gautier-Hion, A., Duplantier, J. M., Emmons, L., Feer, F., Heckestweiler, P., Moungazi, A., Quris, R. \& Sourd, C. (1985). Coadaptation entre rhythmes de fructification et frugivorie en forêt tropicale humide du Gabon: mythe ou réalité? Rev. d'Ecol. (Terre et Vie) 40: 405-34.

Gautier-Hion, A. \& Michaloud, G. (1989). Are figs always keystone resources for tropical frugivorous vertebrates? A test in Gabon. Ecology 70: 1826-1833.

Hart, T. B. (1995). Seed, seedling and sub-canopy survival in monodominant and mixed forests of the Ituri Forest, Africa. $J$. Trop. Ecol. 11: 443-459.

Herrera, C. M. (1995). Plant-vertebrate seed dispersal systems in the Mediterranean: ecological, evolutionary, and historical determinants. Ann. Rev. Ecol. Syst. 26: 705-727.

Howe, H. F. (1984). Implications of seed dispersal by animals for tropical reserve management. Biol. Conserv. 30: 261-281.

Howe, H. F. (1990). Seed dispersal by birds and mammals: implications for seedling demography. In Reproductive ecology of tropical forest plants: 191-218. Bawa, K. S. \& Hadley, M. (Eds). Paris: UNESCO.

IUCN/UNEP. (1987). The IUCN directory of Afrotropical protected areas. Gland, Switzerland and Cambridge, UK: International Union for the Conservation of Nature.

Johns, A. D. (1987). The use of primary and selectively logged rainforest by Malaysian hornbills (Bucerotidae) and implications for their conservation. Biol. Conserv. 40: 179-190.

Johns, A. D. (1989). Recovery of a peninsular Malaysian rainforest avifauna following selective timber logging: the first twelve years. Forktail 4: 89-105.

Johns, A. D. \& Skorupa, J. P. (1987). Responses of rain-forest primates to habitat disturbance: a review. Int. J. Primatology $\mathbf{8}$ : 157-191.

Jordano, P. (1992). Fruits and frugivory. In Seeds: the ecology of regeneration in plant communities: 105-156. Fenner, M. (Ed.). Wallingford, UK: CAB International.

Kalina, J. (1988). Ecology and behavior of the black-and-white casqued hornbill Bycanistes subcylindricus subquadratus in Kibale forest, Uganda. $\mathrm{PhD}$ thesis, Michigan State University.

Kemp, A. C. (1995). The hornbills. Oxford: Oxford University Press.

Kinnaird, M. F., O’Brien, T. G. \& Suryadi, S. (1996). Population fluctuation in Sulawesi red-knobbed hornbills: tracking figs in space and time. Auk 113: 431-440.

Laake, J. L., Buckland, S. T., Anderson, D. R. \& Burnham, K. P. (1993). DISTANCE user's guide. Fort Collins, Colorado: Colorado Cooperative Fish and Wildlife Research Unit, Colorado State University.

Laclavère, G. (Ed.). (1980). Atlas of the United Republic of Cameroon. Paris: Editions Jeune Afrique.

Lambert, F. R. (1992). The consequences of selective logging for Bornean lowland forest birds. Phil. Trans. Roy. Soc. Lond. B 335: 443-457.

Legendre, P. \& Vaudor, A. (1991). The R package: multidimensional analysis, spatial analysis. Montreal: Départment des Sciences Biologiques, Université de Montreal.

Leighton, M. \& Leighton, D. R. (1983). Vertebrate responses to fruiting seasonality within a Bornean rain forest. In Tropical rain forest: ecology and management: 181-196. Sutton, S. L., Whitmore, T. C. \& Chadwick, A. C. (Eds). Oxford: Blackwell Scientific Publications.

Letouzey, R. (1968). Études phytogeographiques au Cameroun. Paris: Éditions Paul Lechevalier.

McClanahan, T. R. \& Wolfe, R. W. (1993). Accelerating forest succession in a fragmented landscape: the role of birds and perches. Conserv. Biol. 7: 279-288.

McDonnell, M. J. \& Stiles, E. W. (1983). The structural complexity of old-field vegetation and the recruitment of bird-dispersed plant species. Oecologia 56: 109-116.

Powell, G. V. N. \& Bjork, R. (1994). Implications of altitudinal migration for conservation strategies to protect tropical biodiversity: a case study of the resplendent quetzal Pharomachrus mocinno at Monteverde, Costa Rica. Bird Conserv. Int. 4: 161-174.

Powell, G. V. N. \& Bjork, R. (1995). Implications of intratropical migration on reserve design: a case study using Pharomachrus mocinno. Conserv. Biol. 9: 354-362.

Raj, D. (1968) Sampling theory. New York: McGraw-Hill.

Sabatier, D. (1985). Saisonnalité et déterminisme du pic de fructification en forêt guyanaise. Rev. d'Ecol. (Terre et Vie) $\mathbf{4 0 :}$ 289-320.

Skorupa, J. P. (1988). The effects of selective timber harvesting on rain forest primates in the Kibale Forest, Uganda. $\mathrm{PhD}$ thesis, University of California, Davis.

Smith, T. B. (1990). Resource use by bill morphs of an African finch: evidence for intraspecific competition. Ecology 71: 1246-1257.

Stiles, E. W. (1992). Animals as seed dispersers. In Seeds: the ecology of regeneration in plant communities: 87-104. Fenner, M. (Ed.). Wallingford, UK: CAB International.

Temple, S. A. (1977). Plant-animal mutualism: coevolution with dodo leads to near extinction of plant. Science 197: 885-886.

Thiollay, J.-M. (1985). The West African forest avifauna: a review. In Conservation of tropical forest birds. ICBP technical publication no. 4: 171-186. Diamond, A. W. \& E. Lovejoy, T. (Eds). Cambridge: International Council for Bird Preservation. 
Thomas, D. W. (1983). The annual migration of three species of West African fruit bats (Chiroptera: Pteropodidae). Can. J. Zool. 61: 2266-2272.

Thomas, S. C. (1991). Population densities and patterns of habitat use among anthropoid primates of the Ituri Forest, Zaire. Biotropica 23: 68-83.

Tutin, C. E. G. \& Fernandez, M. (1993). Relationships between minimum temperature and fruit production in some tropical forest trees in Gabon. J. Trop. Ecol. 9: 241-248.

van Schaik, C. P. (1986). Phenological changes in a Sumatran rain forest. J. Trop. Ecol. 2: 327-347.

van Schaik, C. P., Terborgh, J. W. \& Wright, S. J. (1993). The phenology of tropical forests: adaptive significance and consequences for primary consumers. Ann. Rev. Ecol. Syst. 24: 353-377.

Verdú, M. \& García-Fayos, P. (1994). Correlations between the abundances of fruits and frugivorous birds: the effect of temporal autocorrelation. Acta Oecologica 15: 791-796.

Vitousek, P. M. \& Walker, L. R. (1989). Biological invasion by Myrica faya in Hawaii: plant demography, nitrogen fixation, ecosystem effects. Ecol. Monogr. 59: 247-265.

White, L. J. T. (1994a). Patterns of fruit-fall phenology in the Lopé Reserve, Gabon. J. Trop. Ecol. 10: 289-312.
White, L. J. T. (1994b). Sacoglottis gabonensis fruiting and seasonal movements of elephants in the Lopé Reserve, Gabon. $J$. Trop. Ecol. 10: 121-125.

Whitney, K. D., Fogiel, M. K., Lamperti, A. M., Holbrook, K. M., Stauffer, D. M., Hardesty, B. D., Parker, V. T. \& Smith, T.B. (1998). Seed dispersal by Ceratogymna hornbills in the Dja Reserve, Cameroon. J. Trop. Ecol. 14: in press.

Whittaker, R. J. \& Jones, S. H. (1994). The role of frugivorous bats and birds in the rebuilding of a tropical forest ecosystem, Krakatau, Indonesia. J. Biogeogr. 21: 245-258.

Wiens, J. A. (1989). The ecology of bird communities. Cambridge: Cambridge University Press.

Willson, M. F. (1992). The ecology of seed dispersal. In Seeds: the ecology of regeneration in plant communities: 61-85. Fenner, M. (Ed.). Wallingford, UK: CAB International.

Witmer, M. C. \& Cheke, A. S. (1991). The dodo and the tambalacoque tree: an obligate mutualism reconsidered. Oikos 61: 133-137.

Zhang, S. \& Wang, L. (1995). Comparison of three fruit census methods in French Guiana. J. Trop. Ecol. 11: 281-294. 
